\title{
Automatismo \& Imago. Aportes a la investigación de la imagen inconsciente en las Artes Plásticas
}

Versión final: junio 2012

Jorge Kleiman *

\begin{abstract}
Resumen: El ensayo aborda la cuestión del proceso creativo en las artes visuales. A partir del automatismo psíquico como procedimiento y discursividad artística acuñado por el Surrealismo, se avanza hacia su estudio como proceso complejo que concentra lo intelectivo, lo sensible y lo incosificable. Su fundamentación echa raíces en el Psicoanálisis, la Semiótica y los rastros históricos de las prácticas creadoras. A partir de la propia experiencia artística del autor se ponen en discusión aspectos metodológicos que pueden ser considerados como una sistematización de la inspiración. Para concluir, el texto aporta una reseña del movimiento surrealista y en especial de su impronta en la Argentina a partir del legado formativo de Batlle Planas.
\end{abstract}

Palabras clave: Arte - automatismo psíquico - creatividad - imagen - Pintura - Psicoanálisis Surrealismo.

[Resúmenes en inglés y portugués en la página 135]

${ }^{(*)}$ Artista y Arquitecto (Universidad de Buenos Aires). Docente en la Facultad de Arquitectura, Diseño y Urbanismo (UBA), en IACAT y en la Facultad de Ciencias de la Comunicación, Universidad Santiago de Compostela, España.

Se dicen cosas sólidas a partir del momento en que se deja de tratar de decirlas extraordinarias ${ }^{1}$

(Lautréamont, 1949:252).

\section{Justificación}

Hablar sobre arte es un proceso sustractivo, como colocar un filtro de color ante un objetivo limita la capacidad proyectiva de los observadores. De allí que los maestros de la pintura Zen no explican nada a sus discípulos, se limitan a pintar delante de ellos y a dejarlos pintar. Tampoco mi maestro, Juan Batlle Planas explicaba nada, ni los psicoanalistas suelen hacerlo a sus pacientes; en general parece haber consenso acerca de que no hay nada que enseñar. Tengo entendido que fue Freud quien afirmaba que hay tres tareas imposibles: gobernar, curar y enseñar. Por consiguiente, tampoco hay casi nada que aprender, salvo en la presencia misma del Maestro. Zoroastro el gran mago de la Persia antigua, (el Sarastro de La Flauta Mágica y el Zaratustra de 
Nietzsche), establecía cuatro momentos en la conducta: primero saber, segundo poder, tercero atreverse y cuarto callar. (Fulcanelli 1994:205- 206). A pesar de ello, escribo a sabiendas de que emitir un mensaje que no responda a preocupaciones previas de un receptor es inútil.

Legítimamente podemos preguntarnos porqué me siento autorizado a decir algo sobre el tema propuesto. Lo justifico en más de 50 años (desde 1951, año en que comencé mi trabajo con Batlle) dedicado a la tarea de pescador de las imágenes que se cuelan inadvertidamente al dibujar o pintar sin control inicial con el lápiz sobre un papel o el pincel sobre una tela, en una larga experiencia psicoanalítica personal, en mi formación con Juan Batlle Planas (maestro del Automatismo en Argentina), en las lecturas, los seminarios que seguí sobre la obra de Lacan, la docencia en este campo (ejercida en mi estudio y en centros especializados) y, en fin, en la vida misma.

Creo imprescindible señalar que sólo puedo hablar de tendencias dentro de una dinámica, es decir, de cómo vemos las cosas hoy para información de los investigadores del futuro. La pretensión de encontrar una clave del fenómeno automático dentro de la creatividad supondría considerarla como un hecho fijo e inmutable cuando en realidad es variable, personal y múltiple. De todos modos cualquier afirmación en este campo, por provisoria que sea, debería estar avalada por un trabajo de equipo en el que entren psicoanalistas, médicos, antropólogos, lingüistas, artistas, biólogos, etc., equipo que desde ya invito a integrar.

Haré -a pesar de esta última advertencia- mi pequeña contribución a la marea de información y desinformación con que nos agobiamos unos a otros. Espero sinceramente que tengan al leer este texto la sensación de que ya lo sabían todo desde hace mucho tiempo, pues suele constituir un certificado de novedosa autenticidad.

\section{Introducción a la pintura como discurso}

Debemos confirmar aquí que el hecho de hablar sobre arte es incompleto por ser metafórico y alusivo; es referirse a un lenguaje mediante otro lenguaje. Arte es acto y no explicación, nunca nada de lo que digamos será suficiente, todo puede ser cierto, pero no alcanza.

"El hombre puede abarcar la verdad, pero no puede conocerla" (Yeats, 1991:89).

Pienso que la palabra se halla en estos momentos sobrevalorada. También hablar, como todo lo humano, es incompleto. Por otra parte, el arte es universal, no necesita ser traducido a los distintos idiomas, la transmisión del mensaje es instantánea: rara vez observamos una obra más de tres minutos seguidos, ni más de cinco veces en nuestra vida, pero la llevamos incorporada para siempre. Por cierto que también en arte hay obras significantes e insignificantes, puede existir una retórica vana y muchas mentiras, tanto o más que en el discurso verbal, pero son fácilmente identificables y en todo caso suelen hacer menos daño.

Sabemos que el concepto es imagen, primero vemos y luego aprendemos trabajosamente a referirnos a lo que hemos visto. En el Inconsciente hay representaciones a las que aludimos mediante representantes, ya sean palabras o imágenes, lo que constituye su vulnerabilidad pues jamás un representante satisface su cometido en forma completa. Pero un representante palabra no es capaz de cambiar una representación interna, y uno imagen sí lo es.

Llamaremos IMAGO al conjunto de las representaciones internas, e IMAGEN al conjunto de sus representantes simbólicos. Permítaseme decir que hay entre ellas una relación de semejanza 
paralela a la que existe entre los peces, siempre esquivos y fluctuantes, y los pescados, en su obscena calidad de Cosa (Recalcati, 2006).

Cuando hay creación, el hecho pictórico se constituye como signo, es decir es significante y significado todo en uno, ya no es una alusión a otra cosa, sino que se transforma en el acontecimiento mismo, o sea en verbo. De aquí que cabe reivindicar -como ampliaré más tarde- una función que creo esencial del Inconsciente: la Generación. Esta función excede al concepto de líbido, y lo abarca, pues corresponde a toda la historia del Universo y de las especies.

Siguiendo a Jacques Lacan, el Inconsciente está estructurado como un lenguaje (Lacan, 1977:32), pero está compuesto por imágenes. Habitualmente ese lenguaje requiere para expresarse de una lengua. Ahora bien, en las lenguas existen tropos, figuras de la retórica que consisten en usar las palabras con un sentido diferente al que directamente tienen: la metáfora (y su variante, la sinécdoque) y la metonimia. Son licencias semánticas constituidas por las transformaciones, condensaciones, desplazamientos y sustituciones que también se producen en el proceso onírico, en los chistes, en los actos fallidos, en la poesía y, lo que interesa en este artículo, en el arte: se alude a una realidad, pero transformada para hacerla soportable o simplemente más atractiva.

Nos detendremos un instante en dichos tropos, puesto que están determinando la aparición de la imagen pictórica proveniente del automatismo en todos aquellos casos en que ésta no obedezca a impulsos generativos sino como fenómeno proyectivo, como iremos desarrollando.

METÁFORA o TRASLACIÓN: traslada el sentido recto de las voces a otro figurado, en virtud de una comparación tácita. Se puede decir que es apelar a otra palabra o significante para obtener una significación, otro numerador para un mismo denominador de un signo, en la ecuación

$$
\frac{\text { Significante }}{\text { Significado }}=\text { Signo }
$$

Ej.: $\quad$..."las perlas del rocío"... (como si las gotas fuesen perlas), ..."esparciste tus promesas al viento"... (como si fueran semillas), ..."esta vida frágil y liviana"... (como si fuera una materia o substancia).

METONIMIA o TRANSNOMINACIÓN: Se puede decir que constituye otro significado atribuido a una palabra para obtener una significación, otro denominador para un mismo numerador de la ecuación signo. Viene dada generalmente por relaciones de cercanía entre las cosas Es un deslizamiento del significado que se otorga a las palabras para significar otra cosa. Lleva así implícita una mentira, algo de equívoco.

Ej.: “.. leer a Virgilio...” por "leer las obras de Virgilio".

“... a Jaimito le gusta la botella...” por "a Jaimito le gusta beber en exceso”.

“... poseía treinta cabezas..." en lugar de reses,

De aquí surge la posibilidad misma de la interpretación de las formas en el proceso artístico y de los contenidos en la tarea psicológica, pero con la melancólica convicción de que una inter- 
pretación nunca estará a la altura del hecho, del mismo modo que las respuestas no están nunca a la altura de las preguntas.

Cualquier tipo de creación artística, y por lo tanto cualquier tipo de interpretación de sus contenidos, debe tener en cuenta esos mecanismos básicos de alusión, de transformación alegórica que se dan también en la palabra, con la cual estamos más familiarizados. Pero además hay otro mecanismo -cuya reivindicación constituye uno de los motivos de esta comunicación-, que sigue las dinámicas del Génesis y de la Genética, que han quedado grabadas en la substancia misma de nuestro cuerpo y psiquismo, y que en el lenguaje viene dado por el verbo y sus manifestaciones, los verbos y las dinámicas creadoras. Volveremos sobre esto.

Cabe apuntar aquí que si el lenguaje tiene dos ejes, el sintagmático, que se desarrolla en el tiempo y espacio que dura una frase, y el sistemático, que se despliega en el conjunto, en la secuencia del discurso de un autor, en su sucesión evolutiva (o involutiva) a lo largo del tiempo, también en la obra de un artista interesan el hecho en sí mismo de un trabajo (sintagma) y además el conjunto de su obra a lo largo de su vida, la forma en que se van sucediendo los fenómenos que produce (su sistema), ya sea congruente o quebrada, que constituye finalmente su estilo y su legado.

\section{La obra de Arte}

No puedo usar esta palabra sin recordar que para los alquimistas medievales, la Obra consistía en la transformación del Mercurio en Oro. Dicho sea de paso, hoy sabemos que están uno al lado del otro en la Tabla Periódica de los Elementos en Química, y que los separa la presencia de un solo electrón en órbita. La operación fundamental, que además constituía su lema, era: "SOLVE ET COAGULA", disuelve y coagula, que es precisamente lo que hacen los pintores: disuelven el óleo, acuarela, etc. y lo dejan coagular una vez aplicado sobre un soporte de papel o tela, con lo cual algunos consiguen bastante oro, por cierto.

Podemos considerar la obra de arte como un hecho dado por tres componentes o situado en relación a tres ejes cartesianos que, a su vez, pueden constituirse en un aparato para la crítica:

- eje de las X, de las abscisas o de las ideas, dedicado a lo conceptual.

- eje de las Y, de las ordenadas o de las sensaciones, dedicado a lo sensible.

- eje de las Z, de las alturas, o de las fuerzas puestas en juego, para lo energético.

\section{El eje conceptual}

Es el referido a qué es lo que se hace, cómo se inscribe dentro de la corriente de ideas de un tiempo histórico determinado; es lo que diferencia la Geometría del Cubismo o del Pop Art, a Dadá del Surrealismo por ejemplo. En relación a él se inscribe una Política intrínseca al hecho artístico. Se puede hacer una obra muy bella o grata desde el punto de vista sensible pero desubicada en relación con su época desde el enfoque conceptual. Estos valores, los conceptuales, son pasibles de ser intelectualizados y pueden ser objeto de discusión, y de hecho lo son. Una obra puede estar bien ubicada conceptualmente pero unánimemente rechazada desde el punto 
de vista sensible, por provocar desagrado. Ésta fue la suerte de la obra de Picasso al comenzar el cubismo: aún hoy, una de las obras fundacionales de la pintura moderna como es Las Señoritas de Aviñón no aparece precisamente como bella en un sentido clásico del término.

\section{El eje sensible}

Se refiere al placer, todo aquí es subjetivo. Se habla de armonía, de ritmos -o aún peor, de euritmia-, de valores plásticos, de belleza, de composición, palabras casi vacías que ocultan en última instancia un "me gusta" o "no me gusta". Esta vertiente es variable con el tiempo a través de las generaciones, y dentro mismo del historial individual nuestra sensibilidad cambia. Estos valores no son objeto de discusión, se zanja con un "Sobre gustos no hay nada escrito...”. Desde el punto de vista sensible hay que tener ojo para ver, no se puede enseñar, es una accesis a un hecho innombrable, este es el sitio preciso donde el lenguaje vacila e incluso fracasa: un color se describe como "agrio" o "ácido" como si fuera un sabor, la confusión es total: un sonido es "alto" o "bajo", y su conjunto se organiza en alturas, tensiones, ataques e intensidades (Paz, 1972); un vino se describe como "áspero", término reservado para el tacto y no para el gusto, etc. Lo sensible es el reino donde terminan las palabras, debemos renunciar a conceptualizarlo, por lo tanto no seguiré ocupándome de ello. A sentir se aprende sintiendo.

\section{El eje energético}

Es el menos considerado de los tres. Las energías internas son de tipo genético-libidinal y de tipo genésico. Las primeras son herederas de las fuerzas biológicas que nos formaron, vieron nacer y crecer. Las segundas son las resonancias que aun permanecen de los procesos de Creación Universal que fueron dando lugar a los elementos químicos y fuerzas físicas de las que estamos hechos y a las que respondemos. La componente energética es el grado de fuerza con que se pone en marcha el proceso que da lugar a la obra, es la energía con que se la hace nacer, aglutinando y empleando como materias primas los datos que aportan las vertientes conceptual y sensible, y que luego nutre a los observadores

Se trasluce en los rasgos llamados gestuales, que a "grosso modo" se pueden clasificar en dos tipos: en una obra rápida se privilegia el trazo, la pincelada, la acumulación de materia, el desplante, la frescura e inmediatez; o bien en una obra lenta se emplea la subdivisión de la pasión en un trabajo largo, cotidiano y tesonero, con obstinato rigore. Se introduce aquí el concepto, la vivencia y la relación con el Tiempo, de importancia fundamental para un artista: su vida suele ser asimilable a una carrera con o contra el Tiempo. El primer tipo de pintura, la rápida se relaciona con ciertos aspectos del Zen, del vivir más y pensar menos, es el reino de la espontaneidad. Algunos tipos de pintura oriental y el Informalismo de los años 50 del siglo pasado son buenos ejemplos, también Pollock con su Action Painting y De Kooning en el grupo Cobra. Nada de elaboración, vale el arranque vivaz, el instante pasajero apresado en el gesto, no se dibuja previamente. El segundo tipo de pintura requiere una estructura intelectual, un armazón racional, se va armando por aportes sucesivos de esfuerzo y pensamiento, se privilegia el acabado perfecto, la congruencia total entre las partes. La obras de pintores como Rafael, Leonardo 
Da Vinci o Antonello da Messina y las tablas flamencas del Siglo XV son los ejemplos extremos de esta actitud, para la cual la pintura es cosa mental (cf. Leonardo).

Ambas vías de expresión representan en el fondo distintos acomodamientos de la energía interna, que pueden tener similares diferencias de potencial, que son igualmente respetables, con muchas situaciones intermedias. Por otra parte, creo que todos somos capaces de las dos actitudes y esto hace al concepto de apuntalamiento en diferentes centros energéticos, que transmitieron Fedora Aberastury (1991) y Juan Batlle Planas por tradición oral. Si lo aceptamos como hipótesis de trabajo podemos insertar dos tesis cuya demostración no será matemática sino vivencial:

1. La obra de arte es una radiografía de los acondicionamientos energéticos de la persona que la produce, y el papel, la tela o la arcilla son las placas sensibles que las registran.

2. Las diferentes componentes de nuestra estructura psicológica tienen su correlación en los distintos enlaces que se pueden producir, a manera de circuitos, entre los núcleos o centros energéticos internos.

Hablamos de la Energía; debemos tratar de precisar a qué nos estamos refiriendo. Parafraseando una famosa ecuación podríamos enunciar que:

\section{la Energía humana es igual a la}

Masa del Ser multiplicada por el cuadrado de la Intensidad del Deseo.

$$
\mathrm{E}_{\mathrm{H}}=\mathrm{M}_{\mathrm{S}} \mathbf{x} \mathrm{I}_{\mathrm{D}}^{2}
$$

llamando Masa del Ser al conjunto del Cuerpo más la Psiquis más la Cultura. El hecho de que la Intensidad del Deseo entre al cuadrado en la ecuación nos permite comprender cómo seres no muy dotados física, psicológica o culturalmente, es decir con poca Masa, pueden hacer una obra de gran potencia. En Política se observa esto en forma muy patente.

\section{El automatismo}

Apoyándose en parte en la experiencia del automatismo André Breton lanzó en 1924 el Movimiento Surrealista cuya fertilidad continúa hasta hoy y se proyecta hacia el futuro, a pesar de que sospechosamente se lo da por muerto a cada momento o se intenta desprestigiarlo periodísticamente asimilándolo al absurdo y al disparate. Según el Diccionario de la Real Academia Española (Vigésima Primera Edición): "automatismo: ...ejecución de actos diversos sin participación de la voluntad".

Precisando, según mi visión:

Automatismo: movimiento libre del espíritu que se expresa mediante un discurso verbal, de texto, de imágenes, dinámicas corporales o de cualquier otro tipo, respondiendo a las pulsiones, necesidades, demandas, deseos y emociones, generalmente inconscientes, de los sujetos actuantes y las de la sociedad de su época.

El automatismo pictórico es una forma de asociación libre de movimientos gráficos o de man- 
chas que o bien generarán o bien se traducirán proyectivamente en imágenes.

Dentro del mundo de lo Imaginario tenemos que hacer aquí una necesaria diferenciación entre Fantasía, Imaginación, la Paranoia Crítica y el Automatismo como fuentes de la imagen:

La Fantasía, como el sueño, parece ser, lo mismo que la ensoñación diurna, un producto espontáneo del psiquismo y da lugar a la pintura fantástica, conocida desde hace siglos. Trae aparejadas características formales muy peculiares, casi cinematográficas, como se pudo apreciar paradigmáticamente en la película Fantasía de Walt Disney, y sus numerosas manifestaciones para el mundo de la niñez y la adolescencia, que al ser traducidas pictóricamente, reducen considerablemente su interés.

La Imaginación no es ya espontánea sino provocada voluntariamente, es un producto del intelecto, de "cocina intelectual", un deseo de inventar. Gran parte de la obra de Salvador Dalí es un ejemplo; Archimboldo, Jerónimo Bosch, son algunas importantes referencias del pasado. Veamos lo que nos dijo Benedetto Croce al respecto: “... la imaginación es parasitaria, apta para combinaciones extrínsecas, no para engendrar el organismo y la vida.” (1992).

Salvador Dalí presentó, alrededor de 1930, una variante espectacular que llamó Paranoia Crítica (Dalí, 1935). Frecuentemente la imagen daliniana es un producto interpretativo-paranoide del aparato psíquico. Los elementos de la realidad, por ejemplo figuras representando esclavos y una compotera, son unidos, leídos de otra manera para proyectar sobre sus líneas, valores y colores componentes, el busto de Voltaire ${ }^{2}$; un racimo de uvas se convierte en la grupa de un caballo y en una calavera: la trama externa provee la red que atrapa una casi convincente pero falsa interpretación del mundo, como la de la paranoia. Según parece, el concepto de paranoia crítica daliniana influyó en Lacan, como se señala en un artículo de Patricio Schmitt:

Jacques Lacan frecuentó el grupo surrealista. Hay que recordar ese hecho, generalmente descuidado, sino olvidado. Importante descuido. Pocos autores se detienen en esa etapa del periplo lacaniano y menos aún en su incidencia sobre el pensamiento del Maestro. Uno de ellos, con todo, Sarane Alexandrian en El Surrealismo y el Sueño (Gallimard, París1974, Pág. 67-68) aporta informaciones que levantan una punta del velo. Afirma que la formación de Jacques Lacan debe mucho a su frecuentación del movimiento surrealista, sobre todo a Salvador Dalí. Es notorio que en dichas circunstancias Jacques Lacan era quien hacía las preguntas. Ya que Sarane Alexandrian invita al estudio "de la influencia de Dalí sobre el pensamiento de Lacan”, veamos en qué consiste.

Dalí-Lacan: dos nombres que, al relacionarlos, atraen invariablemente el término común de paranoia. Por una parte, el método paranoico crítico, "instrumento de primer orden" (André Breton: ¿Qué es el Surrealismo? Henríquez, Bruselas 1934) con el cual Dalí parte "a la conquista de lo irracional" (S. Dalí: La Conquista de lo Irracional Edic. Surrealistas, París 1935) y dinamiza el grupo surrealista parisino, que amenazaba languidecer en sus luchas internas. Por otra parte una tesis: Jacques Lacan, La Psicosis Paranoica en sus relaciones con la personalidad (Edit. Le François, Paris, Oct. 1932, reedit. Por Seuil, 1975) que, en octubre de 1932 hace célebre a su autor y lo lleva "al umbral del Psicoanálisis" (Jacques Lacan: Una cuestión preliminar a todo tratamiento posible de la psicosis Edit. Du Seuil, Paris 1955.- "Ecrits" 1966, pág. 536). (Schmitt, 1980). ${ }^{3}$ 
El Automatismo, en cambio aporta imágenes que son un producto estructural del aparato psíquico. Si la carga energética que produce el movimiento no sale de la voluntad conciente, es al Deseo inconsciente al que debemos atribuirlo.

\section{Automatismo es movimiento}

y por lo tanto, energía, ya sea que se realice en el campo de la palabra, de la plástica, la música o con las distintas expresiones que utilizan el cuerpo como medio y tiene como función permitirnos un acceso a lo Imaginario, haciendo un puente o by pass para eludir la acción controladora superyoica. La energía del automatismo es una fuerza que como todas las otras tiene potencial y dirección, necesita para originarse una diferencia de cargas o de signos entre dos lugares del espacio y el tiempo internos.

Naturalmente que no hay artista o escritor que no haya utilizado el automatismo, sin saberlo: se lo llamaba inspiración, e incluso era a veces provocado por ingentes cantidades de alcohol (cf. Henry Miller) o de drogas (cf. Baudelaire, Artaud...).

\section{El automatismo es la sistematización de la inspiración}

Mediante él la originalidad ya no es un fenómeno deseable, sino que es inevitable, del mismo modo en que las impresiones digitales, los rasgos faciales, el timbre de la voz, la letra manual, etc. son siempre individuales. Cada persona tiene propias, únicas e intransferibles, sus radios de curvatura, largo de líneas, deformaciones, tiempos y colores característicos.

Muy pronto descubrió Breton que este método aportaba imágenes que resultaban diferentes de las que surgían en los sueños y estableció ambos campos como vertientes de la imagen inconsciente, privilegiando el automatismo como el sistema más confiable a los fines creativos puesto que tanto el relato de sueños como su representación pictórica son referenciales, descripciones a posteriori, y por lo tanto susceptibles de ser enturbiados por otras instancias:

El automatismo, heredado de los médiums, habrá sido constantemente en el surrealismo una de las dos grandes direcciones. Como es él quien suscitó y suscita todavía las más vivas polémicas, nunca será demasiado tarde para tratar de penetrar un poco más en su función, para intentar aportar al debate un argumento decisivo en su favor....Sostengo que el automatismo gráfico, tanto como el verbal, sin perjuicio de las tensiones individuales profundas que tienen el mérito de manifestar y en cierta medida de resolver, es el único modo de expresión que satisface plenamente al ojo o al oído realizando la unidad rítmica (...), la única estructura que responde a la no-distinción, cada vez mejor establecida, de las funciones sensitivas y de las funciones intelectuales (y por eso es el único que satisface igualmente al espíritu). Que el automatismo pueda entrar en composición, en pintura como en poesía, con ciertas intenciones premeditadas, lo concedo; pero corremos gran riesgo de salir del surrealismo si el automatismo deja de caminar por lo menos bajo la roca ${ }^{4}$ (Breton, 1973:188). 
El automatismo es el hecho creador en sí mismo, y nos otorga las imágenes de una "irracionalidad concreta" (Dalí, 1935). La importancia del Surrealismo radica en que introdujo a plena conciencia no un cambio de temática sino de fuente de la imagen, un cambio de dinámica creadora. Los mecanismos de producción de imágenes a través del automatismo pueden sintetizarse, siguiendo lo visto en el capítulo anterior, en dos grandes grupos, a los que corresponden diferentes herramientas pictóricas:

Primero:

El de la Generación dinámica: la imagen se engendra y desarrolla como un organismo vivo, a través del movimiento. Resulta siempre sorprendente y tiene su origen y explicación en las dinámicas genésicas cósmicas y en las dinámicas genéticas biológicas. Para acceder a ellas preferiblemente usaremos el grafismo, es decir a líneas trazadas con cualquier elemento que deje un rastro. En el automatismo genésico y genético la imagen no se proyecta sino que se va integrando como un embrión que se desarrolla, nace y crece de los fenómenos energéticos puestos en juego.

Segundo:

Los mecanismos Proyectivos: ocurren cuando, sobre una acumulación de líneas o manchas, o en la disposición de las nubes o simplemente sobre marcas de humedad en un muro (cf. Leonardo), proyectamos una imagen interpretando en forma delirante esos materiales. Esta interpretación viene dictada por nuestros contenidos inconscientes, se presentan mediante los mismos tropos que aparecen en el uso de la palabra. Este camino ya fué indicado por Oskar Pfister en Kryptolalie, Kriptographie und unbewusstes Vexierbild bei Normales, aparecido en el Jahrbuch für Psychoanalystiche und Psychopathologische Forschungen, tal como señala Freud en Un Recuerdo Infantil de Leonardo da Vinci de 1913 (Freud, 1948) al descubrir la doble imagen de un buitre entre los ropajes del cuadro Santa Ana, la Virgen y el Niño.

Leamos al mismo Leonardo:

(...)porque arrimando a una pared una esponja llena de varios colores, quedará impresa una mancha que parecerá un país. Es verdad que en ella se ven varias invenciones de aquellas cosas que pretende hacer el hombre, como cabezas, animales diversos, batallas, escollos, naves, nubes, bosques y cosas así: pero es casi como la música de las campanas, que dice lo que a tí te parece que dice... (1980:6).

(...) cuando veas alguna pared manchada en muchas partes, o algunas piedras jaspeadas, podrás mirándolas con cuidado y atención advertir la invención y semejanza de algunos países, batallas, actitudes prontas de figuras, fisonomías extrañas, ropas particulares y otras infinitas cosas; porque de semejantes confusiones es de donde el ingenio saca nuevas invenciones. (1980:8).

El juego complejo de deformaciones, condensaciones y desplazamientos entre las diferentes figuras que van apareciendo agrega un factor dinámico al proceso de pesca de las imágenes inconscientes, que pugnan por adquirir predominio unas sobre otras y quedar como "signi- 
ficante amo" en cada trabajo. De allí que cada dibujo o pintura se convierte en una verdadera aventura del espíritu.

\section{Procedimientos}

Creo que un conjunto de ideas resulta valedero si es fértil, en el sentido de que, al aplicarlas, cada investigador descubra su propio camino, o por lo menos la puerta que le permita iniciarlo. Intentaré describir mi experiencia para que pueda servir de antecedente para otros.

En un primer momento el pintor apela al sistema nervioso vegetativo o proceso primario tratando de hacer un puente que lo integre en lo posible al sistema central. Para ello, recomiendo adoptar una actitud de despersonalización y dejar que la mano haga los movimientos del dibujo por sí misma, sin controles ni propósitos, pero observando lo que sucede, estableciendo un verdadero puente ojo-mano de dirección reversible, sin dirigir por la conciencia. Se van acumulando líneas y colores, es decir energías iniciales que no son casuales sino -postulo- dirigidas desde el primer momento por el Inconsciente para lograr su propósito de expresarse aunque de manera distorsionada. Lo que parecía un conjunto de líneas o manchas azarosas resultará ser un fenómeno objetivo, respondiendo al concepto de Breton: el azar objetivo (Cf. Nadja, novela del encuentro fortuito...). Las formas resultantes del Proceso Primario o lanzamiento automático energético, deben ser interpretadas por el artista como forma, en su contenido manifiesto, no necesariamente en sus contenidos inconscientes, para lo cual sería imprescindible una experiencia analítica en el seno de la cual el artista aporte su material asociativo. Intentar la interpretación sin dicho material sería una experiencia que ha sido denominada como "silvestre" por el mismo Freud en Psicoanálisis Silvestre, de 1910 (1948).

A dicho primer momento de lanzamiento automático sucede otro, el de la elaboración del material obtenido o proceso secundario, en el que aparentemente la conciencia toma un papel preponderante pero que en realidad está tan gobernado por el deseo de expresar el contenido inconsciente como el primer momento. Al proceso primario se suma el secundario, no se excluyen recíprocamente. Este momento consiste en un trabajo de interpretación de la forma, y su gradual esclarecimiento, como quien va sacando un pez del agua hasta tenerlo fuera y bien concreto. Aquí intervienen todas las componentes del ser que está trabajando, su intelecto, su cultura, las influencias sociales, etc. No debemos pues confundir automatismo con rapidez, improvisación ni espontaneidad. Es una objeción muy común el plantear que al haber una elaboración conciente de los materiales iniciales, ya no hay automatismo: ocurre que dicha elaboración está tan dirigida por nuestro Inconsciente como el lanzamiento pulsional inicial, sólo que al darle más tiempo se va enriqueciendo, aclarando y madurando al ritmo propio de los aportes inconscientes, que es lento en relación a nuestra ansiosa avidez de conocer y "pescar" la imagen. Un tema de gran importancia, que parecería oponerse a la predeterminación inconsciente de la imagen automática es el de la intervención del Azar. Es muy cierto que no todo ocurre por necesidad pero hasta en las más azarosas distribuciones se están encontrando leyes físicas que rigen el caos aparente. Y aunque no fuera así, el caos es aprovechado como trama, como sustento para las proyecciones inconscientes.

El grafismo y la mancha son pues las dos herramientas básicas del automatismo, y dan acceso a niveles de diferente profundidad. El primero es más proclive a proporcionarnos contornos de 
figuras, que, a menudo, en su posterior elaboración con sombras y colores pueden revelar la auténtica imagen que esconden; son más fáciles de racionalizar, de distorsionar y admiten con más facilidad la operatividad de filtros, de defensas; suelen dar acceso a escenas de conflicto familiar, o a paisajes, o bien a engendrar células, tejidos y otros elementos biológicos, como se detalla más adelante. La mancha, en cambio, al elaborarla, da acceso a niveles aun más profundos desde el punto de vista emocional, mucho más reprimidos, que nos toman aun más de sorpresa.

(...)La selección opera, en efecto, sobre los productos del azar y no puede alimentarse de otra forma; pero opera en un dominio de exigencias rigurosas donde el azar es desterrado. Es de estas exigencias, y no del azar, que la evolución ha sacado sus orientaciones generalmente ascendentes, sus conquistas sucesivas, el crecimiento ordenado del que ella parece dar la imagen. (Monod, 1970: 133).

El proceso de creación pictórica desde el punto de vista energético - libidinal en el automatismo reconoce tres etapas esquemáticamente:

- primero crisis, que es una gradual acumulación de energía, vamos agregando líneas, manchas, colores, hay un aumento paulatino de tensión y carga

- segundo climax, que es el instante de la iluminación, que antiguamente se llamaba "inspiración": en ese momento vemos la imagen, es como una chispa que surge del trabajo hacia nosotros, tomamos contacto con la creación.

- tercero lisis es el momento de una elaboración lenta, gradual y placentera, se va redondeando la obra, llevándola a su terminación y acabado. Como se puede advertir, en este desarrollo se sigue un símil de las etapas de un acto sexual.

Justamente un aspecto delicado en la acción de crear es la determinación del momento en que la obra está terminada, parecería que las hay terminables y otras que no lo son tanto, o directamente interminables. Un enfoque postula que, al volver a verlas en distintos momentos, se las puede retomar indefinidamente y estaría más completa cuanto mayor cantidad de facetas y estados del artista se presenten, pero otro enfoque afirma que es mejor repartir sus distintos componentes en diferentes trabajos; se aceptaría que una obra representa un momento y que es la sucesión de las obras la que daría testimonio de un ser, que alcanzaría significado a través de todos los significantes que produzca. Lo más común son las posiciones intermedias, la obra se sigue hasta el momento en que tiende a transformarse en otra, en que el proceso de gestación corre el peligro de convertirse en maceración; allí debe haber un "punto de basta", debe nacer el producto en este esquema biologicista de la pintura. De todos modos hoy en día son raros los casos en que se llega hasta ese punto, los artistas solemos estar demasiado ansiosos y no hacemos como en su tiempo Jan Van Eyck, quien firmó alguno de sus cuadros con la siguiente leyenda: "Als Ich Kan", (Como yo Puedo), lo cual encierra un aparentemente humilde "esto es lo mejor que puedo..." pero también un soberbio "vean todo lo que yo puedo, a ver quién es capaz de hacerlo mejor..."

“(...) Van Eyck firmó este retrato (el de su esposa Margarita) con su lema habitual en letras griegas que deletrean fonéticamente las palabras flamencas ALS ICH KAN (como mejor puedo)” 
(Van der Elst, 1947:101).

El momento en que da su obra por terminada es el más peligroso para un artista, porque es el que marca la magnitud, los límites de sus fuerzas y de su talento.

Las imágenes producto de las dinámicas automáticas se dan en cuatro niveles principales, el actual individual, el histórico individual, el biológico o de la especie y el cósmico o universal. Por cierto que hay campos intermedios, pero podemos ir indicando que parecería existir una evolución potencial que lleva de un nivel a otro gradualmente. Esta evolución puede ir viéndose detenida, estancada, por diversas razones; principalmente por puntos de goce producidos por acontecimientos traumáticos que producen la adherencia, la soldadura de la energía psicobiológica a una etapa de la evolución.

En general las formas que se obtienen no son descriptivas, textuales, sino que traen un cierto grado de distorsión o encubrimiento, a menudo estetizante. Así como la verdad dicha con afecto es una de las bases de una curación psicológica, la imagen expresada con "belleza" se hace aceptable para el público, hay un núcleo afectuoso positivo que actúa automáticamente para endulzarnos un poco la existencia, una capacidad autoanestésica en relación a lo actual, y de olvido, negación o represión en cuanto al pasado, pero que dificulta la tarea de investigación de la imagen inconsciente. Este filtro es extremadamente astuto y cuesta mucho a veces sorprender su solapado accionar: existe el miedo a la aparición de contenidos que no se quieren ver y que pueden producir la sensación de lo siniestro. Únicamente en forma muy gradual se puede llegar a no asustar ni provocar un recrudecimiento de las resistencias. Aquí cabe el estudio de la sublimación, mecanismo planteado pero no desarrollado por Freud, investigado más profundamente por J. Lacan en El seminario VII: la ética del psicoanálisis. Recomiendo nuevamente a quien se interese por este tema el artículo La sublimación artística y la Cosa por Mássimo Recalcati en Las Tres Estéticas de Lacan. (2006).

Tanto en Literatura como en Pintura, la imagen se obtiene por las relaciones entre las partes del discurso, más que por la presencia de formas aisladas que se impongan: "Así como el lenguaje no consiste en palabras sino en una serie de relaciones, también la imagen surrealista no es una descripción sino un acontecimiento, una relación especial surgida a través de un súbito encuentro de términos (...)" (Mead, 1978: 140).

La Psicología de la Forma, al estudiar las Leyes de Segregación de Unidades y de Integración de las Formas afirma: "Las relaciones entre las partes dependen de la estructura de la totalidad (...)” (Arnheim, 1983:96).

Las leyes de Separación de Figura y Fondo según la orientación, el tamaño, la ubicación, la distribución, el color, la textura, la simetría, mantienen su vigencia en el momento de la interpretación de la forma de los elementos producto del proceso primario. A veces hay que hacer una doble trampa al Inconsciente, que consiste en usar lo que se creía que era el fondo como figura y lo que era figura como fondo, en típica maniobra gestáltica.

Un punto importante es el de la bi o tridimensionalidad de las imágenes que se van configurando. Las primeras suelen estar conectadas con procesos mucho más primitivos y elementales, pueden así ser consideradas como provenientes de zonas más profundas del Inconsciente. Las segundas, más cultas, civilizadas y elaboradas, nos conectan con aspectos menos reprimidos y más maduros del aparato psíquico. La cuarta dimensión aparece como siempre en su relación con un desarrollo temporal y está representada por las transformaciones que siguen los elementos que aparecen durante el proceso secundario de elaboración, o bien, en la evolución de 
la imaginería a lo largo de toda la experiencia de un artista.

Relacionado con el aspecto energético de la creación se halla el del timing o ritmo en que el Inconsciente tiene a bien proporcionarnos sus dones: es inútil tratar de acelerarlo, se produce siguiendo un compás biológico y matérico, a la manera en que un elemento radioactivo libera un Quantum de energía para ir convirtiéndose en otro elemento. Asimismo es recomendable observar muy a menudo y durante mucho tiempo los trabajos para darle al perezoso Inconsciente la oportunidad de comunicarse con nosotros. También es frecuente que al volver a ver tiempo después un trabajo terminado, recién advirtamos cuál es su verdadera imagen, que en su día nos pasó inadvertida.

Así como hay un ritmo en el tiempo, hay también una distancia de observación óptima para que un trabajo revele su imagen oculta, que depende de su tamaño: desde un sitio algo alejado, a unas tres o cuatro veces la altura del cuadro u hoja de papel, se descubren sus secretos con mayor facilidad.

También es necesario señalar que la primera imagen que nos propone el Inconsciente suele ser falsa, una cortina de humo que conviene no aprovechar (como parece que ya advertía Picasso: "la primera imagen hay que descartarla...") para profundizar en otros niveles más protegidos. Otro mecanismo de resistencia muy habitual es la aparición de numerosas imágenes pequeñas, que llenan el cuadro dentro de una atmósfera general de "horror vacui": son las temibles micro-imágenes a las que llamo "Las Tentaciones de San Antonio", que disimulan la auténtica, que en general es una macro-imagen. Existe un verdadero conjunto de propuestas engañosas inicial, al que llamamos "Imagen aparente", asociado a los contenidos manifiestos y circunstanciales del sujeto, que en general podemos descartar, para luego llegar a la "Imagen verdadera", mucho más reprimida. Se establece así una suerte de ética del discurso artístico, de discriminación de lo que se acepta y de lo que se rechaza.

\section{Algunas de las dinámicas encontradas}

Las fechas que anteceden a cada anotación, son las de su redacción en el Libro - Diario Pintamientos de mi autoría, en preparación.

10/7/72 Paisajes:

a) a partir de una línea de horizonte quebrada.

b) tejido alrededor de un elemento, por ejemplo dibujando una piedra y luego dejar que vayan apareciendo otros elementos.

Investigaciones anatómicas en forma de Autoretratos ya sea estructurados o blandos, de frente o de perfil.

Ovillos más o menos cerrados y poblados de líneas. Luego se destacan los planos, borrando lo que va quedando detrás y relacionando las formas resultantes entre sí, hasta que aparecen las imágenes por "interpretación de la forma". ${ }^{5}$

Rayitas: yuxtaponer rayitas una al lado de la otra en forma más o menos paralelas al principio y luego dejar que vayan tomando variantes de dirección y de modulación. Pueden combinarse 
con núcleos energéticos, situados o no en los puntos definidores de la estructura humana.

Simetrías: trazar un eje, de un solo lado se dibuja libremente o siguiendo el perfil humano, por ejemplo. Del otro lado se copia lo más fielmente posible lo realizado en forma de simetría especular, ambos dibujos se unen y elaboran como un conjunto.

Elementos biológicos: a manera de células o tejidos, que podrán ser tratados como monumentos arqueológicos, personajes, etc. o no.

15/7/72. Desencadenamientos:

\begin{tabular}{|l|l|c|}
\hline a partir de un punto & $\begin{array}{l}\text { un eje de simetría y las } \\
\text { esculturas resultantes }\end{array}$ & un plano \\
\hline dos puntos & dos ejes, perpendiculares o no & dos planos \\
\hline tres puntos & tres ejes & tres planos \\
\hline x puntos & x ejes & x planos \\
\hline
\end{tabular}

Arabescos: libres y sus interpretaciones delirantes. Pueden ser lineales y/o por acumulación de puntos.

Lanzamientos: hacia lo desconocido a velocidades diversas y variables.

18/1/73: Una cara humana: (o pies, o manos, o combinaciones de esos elementos) tomados como núcleos de energía, y dejar salir todos los fenómenos energéticos a que den origen.

5/77: Una línea, arbitraria y continua, cerrada; investigar las modulaciones de luz y sombra que sugiere.

23/6/77: Los elementos del cuerpo, estructurados independientemente, con distintos colores, sin intentar organizarlos entre sí.

30/6/77: Grafismo de muy pocas líneas, de gran dinámica, y desprender sus consecuencias volumétricas. Nota de Agosto 1996: situarlos en los puntos definidores del ser Humano.

El ser humano como una construcción (consecuencias volumétricas de su perfil) y el paisaje como una escritura, proyecciones de ese ser, formando el todo un paisaje continuo.

14/2/85: Formas cerradas y libres, tangentes entre sí o con escotaduras de enlace, integran la figura. La cabeza o el cuerpo como un conjunto de estructuras articuladas, exagerando-proyectando alguna de ellas. 
3/3/91: Manchas, un gran negro pegado a un gran blanco, todo lo demás en grises diferentes. Elaborarlo hasta la aparición de las imágenes.

11/11/96: Fondo blanco muy pulido: ensuciar con un pincel mojado en los restos de trementina sucia de limpieza, con toda soltura. Luego ir acusando las luces y las sombras, con pinceladas, pintura y color, según las estructuras que sugiera.

A mero título informativo haré una lista de los Modelos de Imagen más frecuentes que van apareciendo en mi caso al trabajar con esos planteos iniciales:

1. Células, tejidos y órganos internos; imágenes propias de la embriología.

2. Esquemas corporales en los que suelen aparecer anomalías, que pueden llamar la atención sobre posibles enfermedades. Podría investigarse este método como auxiliar de diagnóstico,

3. Alusiones a la escena primaria, al embarazo y al parto,

4. Retratos propios y del grupo familiar en que aparecen esquematizados formas de relación entre sus componentes,

5. Episodios traumáticos de cualquier naturaleza que se repiten hasta que pierden gradualmente virulencia, (a manera de una rumiación).

6. Expresión de deseos más o menos condensados o desplazados,

7. Figuras arquetípicas como "el Guardián" o "la Bruja" o "La que Ríe" (asociada generalmente con la muerte), o dioses antiguos representando las emociones o pasiones elementales: Apolo, Artemisa, Zeus, Dionisos, Shiva, o frecuentemente el Demonio.

8. Paisajes en que los horizontes sucesivos determinan una suerte de escritura,

9. Animales, con frecuencia pájaros, ya sea agresivos como el águila o mansos como la paloma, cuya aparición fue inmediata en cuanto se comenzó a trabajar con el automatismo (Cf. el Pájaro Loplop, en Max Ernst), también el toro, el carnero, el lobo, el león, el tigre, la rata y el caballo. Seres mitológicos, como la sirena, hacen su aparición. He observado que a menudo los animales emergentes no corresponden a la fauna actual, sino más bien a sus antepasados lejanos, ya extinguidos o a una síntesis humano-animal (minotauros, centauros, sirenas,etc).

10. También aparecen seres formados por distribuciones energéticas extrañas como si fuesen formas de vida posibles pero fuera de nuestro conocimiento,

11. Una vez que se transciende el terreno de la expresión individual comienzan a aparecer los contenidos universales, ansiedades relativas a la especie en general, preocupaciones metafísicas, cuestiones de principio, la vida y la muerte, la esencia de la luz, cosmogonías, manifestaciones puramente energéticas, etc., que denuncian la sed de absoluto que algunos seres poseen.

12. Estructuras repetitivas que manifiestan mecanismos obsesivos, claramente dependientes de una dificultad o hecho traumático que se ha erotizado y necesita repetirse, como única posibilidad de superación, de digestión,

13. El Ser Humano generando su entorno por mera presencia (antecedente: Oskar Schlemmer: Ballet Triádico), etc.

Pablo Picasso utilizó casi toda su vida una variante a la que podríamos llama Automatismo Aplicado: él sabía de antemano qué era lo que iba a realizar, por ejemplo un busto de mujer sentada en una silla o una cabeza animal, pero dejaba suelta la mano en el momento de dibujar, 
produciendo un verdadero "lanzamiento energético" que estructuraba sus composiciones en forma de dinámica automática, dándoles un atractivo sin par. También Francis Bacon, entre otros, realizó muchas de sus obras del mismo modo.

\section{Selección de "Pintamientos"}

Pensamientos propios referidos al Automatismo, habidos durante el trabajo de pintar:

14/12/76: La imagen se presenta como un visitante que ni siquiera se toma la molestia de tocar el timbre, sino que abre con su propia llave.

10/12/79: A menudo siento un "respeto religioso" por las imágenes que se manifiestan: son "objetos de culto" que me producen sensaciones de reverencia ante el misterio. Es prodigiosa la "no arbitrariedad", o "necesidad absoluta" con que se afirman, lo cual despierta ese "sentido de adoración” dentro de mí.

25/9/95: Obtener una imagen a partir de una madeja de líneas o un conjunto de manchas busca también reconstruir una cadena de significantes, hallando los términos perdidos (o modificando los alterados) de la Serie, del mismo modo en que actúa la Asociación Libre en Psicoanálisis.

6/3/96: Las dinámicas que generan las formas son las que deben engendrar la imagen, no hay azar en ello, es pura lógica.

26/3/96: Es la dinámica creadora lo que interesa, mucho más que las imágenes a que ella da lugar, que son más o menos anecdóticas (Ver la obra de Fräntisek Kupka).

21/5/96: Pienso que no debería el pintor que investiga la Imagen Inconsciente empecinarse en deshacer las condensaciones (metonimias) ni en explicar los desplazamientos (metáforas): el que pueda, que lo vea.

23/7/96: A menudo, al comenzar un trabajo, aparecen ciertos "fantasmas" que constituyen verdaderas "propuestas al significante". ¿Las atendemos o no? A veces sí, otras no. En general provienen de un nivel superficial del Inconsciente. Los niveles más profundos son los más primitivos; llegar a ellos constituye un viaje en el tiempo: estructuras celulares, tejidos, imágenes muy primarias parecidas a las que dibujan los niños y los "salvajes" -más conectados con los elementos de la naturaleza- o componiendo escenas dramáticas. El Inconsciente es un gran director de teatro.

25/8/00: No se podrá avanzar más en el terreno del automatismo gráfico si no se acepta, tolera y subraya el fenómeno de la "condensación", en el cual una misma línea o forma sirve a la vez a dos imágenes diferentes, lo cual nos lleva a una torturante (para un espíritu cartesiano) indefinición final. Al elegir una de las dos imágenes, descartando (sin derecho a ello...) a la otra, 
no por eso desaparece la descartada, sino que a menudo se refuerza al adquirir la categoría de fantasmática, de significado en ausencia, de connotación.

17/6/02: El ojo se agarra de cualquier cosa con tal de cumplir sus fines al servicio del Inconsciente.

23/9/02: Es el claroscuro, no el color, lo que finalmente determina la imagen.

9/10/03: Al comenzar un trabajo se enfrentarán turbulencias íntimas, vórtices cuánticos, convocados por fuerzas que no conocemos, que nos llevarán a emociones y mundos históricos, biológicos e incluso anticipatorios, lo que constituye una "prueba iniciática" (nunca mejor dicho...) siempre reveladora.

30/10/03: Vagos vapores, etéreas alusiones...No intentar arrojar demasiada luz sobre los fantasmas sobrevenidos sin dibujo previo ¡Ah infame sorpresa!: al iluminarlos se convierten en muñecos de papel maché sin vida, o desaparecen... Sólo toleran una cierta claridad. "Sombras, nada más..."

30/6/04: ¿Cuándo un impulso es dictado por el Inconsciente o es producto de la Cultura? Discernir esto es la tarea del pintor surrealista y lleva la vida entera.

5/7/04: No confundir el Azar con el Automatismo. Detrás del primero están las leyes de la Física, detrás del segundo está el Ser Humano.

20/9/04: No pretendas pintar un cuadro volviendo a seguir el camino que ya recorriste con alguno anterior: escucha humildemente la voz del que estás haciendo y haz lo que te pide. A cada momento somos otro y se debe tener el coraje de mostrarlo.

13/10/04: A veces, al retomar un trabajo por las mañanas, me encuentro con importantes sorpresas: ha seguido elaborándose durante mi ausencia.

24/5/05: No se debe reclamar unidad en la obra de quienes trabajen con el Inconsciente. Leemos en Psicoanálisis y Grupalidad, de Armando Bauleo: "El Inconsciente no reconoce ni la negación ni la contradicción; sus elementos componentes son múltiples, quiere decir que no podemos pensar en la unidad ni mucho menos en una síntesis”.(1997:43).

23/4/07: Así como hay una Lógica de la Conciencia, hay otra Lógica del Inconsciente, que resulta implacable una vez establecidas las leyes internas de cada trabajo.

2/5/07: La profundidad de un artista surrealista se puede medir por la cantidad de propuestas significantes que se van apareciendo en cada trabajo, y que rechaza.

1/10/07: Somos irremediablemente tontos: lo más importante de nuestra obra es aquello de lo que no nos damos cuenta. 


\section{Apunte sobre el desarrollo del surrealismo}

Creo fundamental aquí diferenciar claramente que trabajar con el automatismo es hoy condición necesaria pero no suficiente para ser un surrealista. Esto último implica una convicción política revolucionaria, de la que se desprende una ética respecto al manejo de la obra en relación a la Sociedad que excluye la posibilidad de competir con otros artistas en la consecución de premios y por consiguiente, prohíbe la actividad como jurado en todo tipo de concursos. Muy pocos son los espíritus capaces de mantener tales esquemas de conducta como para poder ser considerados surrealistas. Si no se juega con las reglas que la mayoría social respeta, el sujeto queda marginado, aunque sea un adelantado, y eso es muy difícil de soportar porque suele significar hambre.

Es por casi todos conocido que André Breton en 1916 era un joven poeta, en la línea que provenía de la obra de Stéphane Mallarmé y de la presencia de Paul Valéry. Simultáneamente, después de alguna incursión universitaria en la Filosofía, estudiaba Medicina y leía muy atentamente lo ya publicado por Freud, entre lo que figuraba La Interpretación de los Sueños, "Psicopatología de la Vida Cotidiana, Una Teoría Sexual, El Chiste y su relación con el Inconsciente, El delirio y los sueños en la Gradiva de W. Jensen, Un recuerdo Infantil de Leonardo da Vinci y Tótem y Tabú. Explosiva combinación, sin duda. Llamado a las armas en 1915, estuvo en diferentes destinos en calidad de auxiliar médico en neurología para atender entre otros a los soldados aquejados de la llamada entonces "neurosis de guerra" que era nada más ni menos que la normalísima condición de tener pánico y negarse a ir al frente. Para tratar a estos inocentes considerados enfermos por los auténticos psicóticos que habían desencadenado y mantenían la terrible guerra del '14, decidió Breton probar la utilización de la "asociación libre", conquistada por la clínica freudiana, la que había ya descartado la hipnosis y superado un breve período en que probó una suerte de "imposición de manos" sobre la frente del paciente.

Sorprendió a Breton la belleza poética de algunas imágenes obtenidas en el discurso por "asociación libre" y tuvo la idea -que sería fundadora del Surrealismo- de aplicarla en forma sistemática a la creación literaria, siendo seguido poco después por Robert Desnos, Philippe Soupault, Paul Eluard, Louis Aragon, Benjamín Péret, René Crevel y otros. Quedó así sellado el estatuto del Surrealismo como hijo del Psicoanálisis.

Surrealismo: transcribiré la tan conocida definición que da André Breton, iniciador y guía reconocido del Movimiento, en el Primer Manifiesto, de 1924

s., m.: automatismo psíquico puro por el cual nos proponemos expresar, ya sea verbalmente, ya sea por escrito, ya sea de cualquier otra manera, el funcionamiento real del pensamiento. Dictado del pensamiento, en ausencia de todo control ejercido por la razón, fuera de toda preocupación estética o moral". (Breton, 1985:44).

Por cierto, hay que recordar que el cuerpo piensa por su cuenta y que justamente el motivo de esta investigación está en aprender a escucharlo y comprender sus mensajes. El surrealismo exige pintar liberándose del prejuicio estético "clásico" de Belleza. Es una forma de estar "más allá del bien y del mal." 
No haré aquí una reseña histórica del movimiento, que se puede encontrar en publicaciones diversas. Sí afirmo que el Surrealismo no es en 2008, (pues como todos los organismos vivos ha seguido evolucionando) -y me conformaría con que sólo este concepto quede claro- un elefante con patas de araña (Dalí, 1935), ni el "encuentro fortuito de una máquina de coser y un paraguas sobre una mesa de disección"6. Hay que diferenciar definitivamente la Pintura Fantástica de la Surrealista.

Los principales aportes de Breton, además de haber cohesionado al grupo dándole un cuerpo teórico e inclusive una nueva ética, rayana en lo represor y dictatorial (anatemas, expulsiones, etc.), fueron tres conceptos:

- El ya mencionado de sistematizar el acceso a la inspiración mediante el automatismo.

- El principio de que la Belleza es convulsiva o no existe, es decir que se aleja del concepto este tizante habitual para acceder a otro en que se asocia a su capacidad de con-mover, de con-mocionar. La nueva estética debe ser profundamente transformadora, emocionalmente perturbadora, que consiga mover algo dentro nuestro, siguiendo la etimología de la palabra "emoción", en caso contrario la obra es principalmente decorativa y a menudo ni siquiera eso: "La belleza convulsiva será erótico-velada, explosiva-fija, mágica-circunstancial o no existirá". ${ }^{7}$

- El principio del Azar Objetiv (Breton, 1945), en que se relatan encuentros con seres y cosas aparentemente azarosos pero profundamente guiados por el Deseo inconsciente, sin citas previas ni voluntad manifiesta de unión, pero que logran así una temperatura lírica, poética, inigualable. Es en este punto, especialmente, en el que el Surrealismo se convierte en un heredero y continuador de Romanticismo.

No tenía la intención de contar, al margen del relato que voy a emprender, sino los episodios más sobresalientes de mi vida tal como puedo concebirla fuera de su plano orgánico, o sea en la medida misma en que está sujeta a los azares, al menor como al mayor, en que revolviéndose contra la idea común que me hago de ella, me introduce en un mundo como perdido que es el de los acercamientos súbitos, de las petrificantes coincidencias, de los reflejos que predominan sobre toda otra manifestación de lo mental, de los acordes de un solo golpe como en el piano, de los relámpagos que harían ver, pero de veras ver si no fueran todavía más rápidos que los otros. Se trata de hechos de valor intrínseco sin duda poco controlables pero que, por su carácter absolutamente inesperado, violentamente incidente, $y$ el tipo de asociaciones de ideas sospechosas que despiertan, cierta manera de hacerlo a uno pasar del hilo de la Virgen a la tela de araña, es decir, a la cosa más centelleante y más graciosa que existiría en el mundo, si no fuese porque en la esquina, o en las cercanías está la araña; se trata de hechos que, aunque fuesen del orden de la comprobación pura, presentan cada vez todas las apariencias de una señal, sin que pueda decirse con precisión de qué señal, que hacen que en plena soledad descubra en mí inverosímiles complicidades, que me convencen de mi ilusión todas las veces que me creo solo al timón del barco..." (Breton, 1945: 21 y sig.). 
El Surrealismo de hoy se ha volcado en su evolución principalmente al estudio del automatismo y sobre todo al de los aspectos dinámicos del automatismo. Los adelantados de esta posición en Europa han sido los pintores Picasso, Kandinsky, Klee y Max Ernst. En Argentina quienes comenzaron con su práctica fueron José Planas Casas y su sobrino Juan Batlle Planas. Éste último, en algunos sectores de su obra muy fecundos energéticamente, como ser en la etapa de Los Mecanismos del Número (1938/47), bajo la influencia de Wilhelm Reich, señala las primeras investigaciones gráficas con los centros de energía y los desencadenamientos a que dan lugar. No podemos olvidar de mencionar también los numerosos "Juegos Surrealistas", practicados ya por el Grupo original francés, siendo el "Cadáver Exquisito" literario y pictórico el que más frecuentado. Asimismo merecerían un capítulo aparte (que excedería los límites de este artículo) la descripción detallada de procedimientos como el Collage, el Frottage, el Gommage (con tan bellos ejemplos de Abd-el-Kader El-Janabí, quien trabaja en París y otros tipos de Grattages (Raspados), las Decalcomanías de Oscar Domínguez, etc.

Hagamos un pequeño repaso de los nombres de los artistas surrealistas o automatistas más conocidos, sabiendo de antemano que toda lista es incompleta y modificable, con un orden arbitrario y mezclando vivos con muertos: Picasso, principalmente entre 1927 y 1936, y en toda su obra no realista, Kandinsky, Max Ernst, Miró, Masson, parte de la obra de Dalí, de Domínguez, de Brauner, de Duchamp, Bellmer, Hérold, Tanguy, Roberto Matta, Hans Arp, Wilfredo Lamm, Picabia, Toyen, Simón Hantaï, Konrad Klapchek, Magritte, Man Ray, Richard Oelze, Giacometti, Toyen, Valentine Hugo, Esteban Francés, Eugenio Granell, Francis Bacon, Méret Oppenheim, Jimmy Ernst, , Alechinsky, Arshile Gorky, Wolfgang Paalen, Kurt Seligmann, Mario Cesariny, Cruzeiro Seixas, Enrico Baj, Joseph Cornell, Jorge Camacho, Anne Éthuin, Max Svanberg, Agustín Cárdenas, Jean Benoit, Schöendorff, Kay Sage, Günther Gerszo, José y Kati Horna, César Moro, Gerôme Kamrowski, Gordon Onslow Ford, ciertas zonas de la obra de William Baziotes, de Kupka, de Jackson Pollock, de Aaron Siskind, de Frederick Sommer, de Mark Rothko, de Enrico Donati, de Stanley Hayter, de Philip West y otros...

Hay numerosos antecedentes, pintores a quienes no podemos llamar surrealistas pero que estuvieron muy cerca de sus ideas, o incluso coincidieron pero que no quisieron asumir el nombre: Giorgio De Chirico, Paul Klee, Rufino Tamayo, Moore, Wölfli, Xul Solar, los dibujos de Erik Satie, etc.

Hay también numerosas derivaciones y parentelas: el grupo Phases que lideraba el poeta Édouard Jaguer, el Grupo Cobra, con Karel Appel y Lucebert. El Arte Pop, movimiento que unió la influencia surrealista de los emigrados a USA por la II Guerra Mundial con la influencia de la publicidad; Dubuffet, etc.

Existen en la actualidad Grupos Surrealistas funcionando en los siguientes sitios (lista incompleta, como lo son todas):

- España: en Madrid: Eugenio Castro, José Manuel Rojo, Javier Gálvez, Giordano Bruno, Concepción Benito, Lurdes Martínez; en Santiago de Compostela la fundación Granell...

- Inglaterra, con: John Welson y el Grupo de Leeds,

- Chicago, USA.: reunidos por los esposos Rosemont, revista "Arsenal".

- París: con Vincent Bonoure, Guy Girard, Michaël Löwy, Marie-Dominique Massoni, Ody Saban, Jean Louis Bédouin, Abd El Kader El-Janabí (Akej) y el Grupo Phases.

- Praga: reunidos por Jan Svankmajer, revista "Analogon", 
- Dinamarca: reunidos por Frank Antonsen,

- Puerto Rico: reunidos por Daniel del Valle Hernández, revista "El Dragón Verde”,

- Buenos Aires: reunidos por Silvia Grenier, revista "Signo Ascendente", ya sin continuidad.

Actualmente hay individuos aislados, sin integrar un grupo.

- Colombia: reunidos por Raúl Henao.

- Estocolmo: reunidos por Johannes Bergmark y Bruno Jacobs.

- En Montreal, reunidos por Pierre Boulay y Gilles Peticlerc, revista "la Tortue-lièvre".

- Bucarest: reunidos por Gellu Naum,

- Chile, con el Grupo Derrame alrededor de Aldo Alcota y Rodrigo Hernández; Enrique de Santiago, etc

- Portugal, con Miguel de Carvalho y Cruzeiro Seixas, entre otros,

- Brazil, agrupados por Sergio Lima, Floriano Martins y Claudio Willer,

- Alemania, con Heribert Becker en Colonia, etc.

\section{El Automatismo en la plástica argentina}

El automatismo en la plástica argentina tuvo un origen español. Supongo que este aserto será gratificante para los españoles, habida cuenta que en tantos otros campos es mayor la influencia inglesa o francesa en nuestro país.

El primer personaje, José Planas Casas, nacido en Cataluña en el año 1900, llegó a Buenos Aires en 1911. Trabajó como grabador y pintor. Ejerció la docencia artística, fue titular de la cátedra de escultura en la Escuela de Bellas Artes de Santa Fe y llegó a dirigirla durante los últimos años de su vida. La obra que dejó es bastante escasa en cantidad pero de alta calidad y sirvió como antecedente para la del sobrino, Juan Batlle Planas.

Es en 1930 cuando se pueden fechar las primeras experiencias con el automatismo realizadas por Planas Casas y Juan Batlle Planas, que tenía entonces 19 años de edad, y que resultaría la figura principal de la plástica surrealista en Argentina.

Para ganarse la vida, tío y sobrino trabajaban juntos en ese momento en un taller de grabado artesanal y orfebrería, haciendo moldes de letras para imprentas, botones, hebillas para cinturones (vi algún trabajo de Batlle en exquisito Art Nouveau).

Juan Batlle Planas fue traído de Cataluña en 1913 con dos años de edad y nunca saldría de Argentina, salvo una breve estadía en Uruguay. Hace entre 1928 y 1931 una experiencia Zen con un ingeniero japonés a quien considerará luego toda su vida como el hombre más importante que había conocido. Al mismo tiempo estudia la obra de Freud, que dejará en él una profunda impronta. Dio conferencias sobre su pintura en varias instituciones, entre ellas la Sociedad Argentina de Medicina Psicosomática.

En 1934 y 1935 realiza numerosos dibujos a lápiz con técnica automática y los expone en 1935, en el Segundo Salón de Artes Plásticas. En el mismo año, bajo cierta influencia de Torres García realiza trabajos a la témpera con particiones rectangulares y dibujos automáticos en cada una de ellas. De 1936 datan sus primeras Radiografías Paranoicas. En 1937 colabora con el arquitecto Antonio Bonet en la urbanización de la Bahía de Portezuelo, en Punta del Este, Uruguay, con el proyecto de elementos escultóricos para poner en la playa, que no llegan a realizarse.

En 1939 hace su primera exposición personal con collages en el vestíbulo del Teatro del Pueblo. 
En 1944 exhibe sus trabajos sobre los ritmos energéticos en la Galería Müller de Buenos Aires. En 1949 realiza una retrospectiva (1935/49) en el Instituto de Arte Moderno. En 1951 -fecha en que lo conocí y comencé mi formación con él- y en 1955 expone en la Galería Bonino de Buenos Aires. En 1956 en la Galería de Arte Selecta, de Roma. En 1959, exposición de 106 obras en orden cronológico en el Museo Nacional de Bellas Artes de Buenos Aires. En 1960 la Academia de Bellas Artes le otorga el Premio Palanza y desde 1962 es Académico de Número. En 1965 la Embajada Argentina en Washington organiza una muestra de sus trabajos. En total hizo 98 exposiciones individuales y 580 de conjunto.

Fue además poeta, escenógrafo, escultor y maestro. Muere por un derrame cerebral, lo mismo que había tenido su madre y su hermano poeta, Joaquín, el 8 de octubre de 1966 a los 55 años de edad, en plena madurez creativa. En 1981 el Museo Nacional de Bellas Artes hace una gran exposición de sus obras. También la Fundación Alón de Buenos Aires exhibe una notable selección de sus trabajos, con un excelente catálogo-libro, en 2006.

Detallaré las componentes más destacadas de su obra:

1) El empleo de los "Centros de Energía", que consiste en el predominio de un automatismo energético a partir de ciertos núcleos en forma de Puntos Negros que organizan la imagen con amplios movimientos curvos, muy sueltos, como de ondas, fue la dinámica que lo llevó a la parte más importante de su trabajo, que es, a mi juicio, la de los Mecanismos del Número, que va aproximadamente entre 1943 y 1948. Tiene una clara raíz en el Románico Catalán, por ejemplo el de San Clemente de Taull, que a su vez rinde tributo a la estética bizantina, y que Batlle llevaba consigo como patrimonio cultural congénito. Ver también San Pedro de Burgal, todas del Siglo XIII. Esa experiencia, que adquiere por momentos una expresión dramática lo lleva en 1947 a una crisis profunda: se había adelantado demasiado a su tiempo y tuvo que pagar el precio que eso comporta. El poeta Lorenzo Varela nos describe esa etapa, en su prólogo al catálogo de la exposición de Washington: "Por un momento deja la pintura, cree que para siempre, y piensa, muy seriamente, estudiar medicina. La crisis tiene relación, según confiesa con el shock que le producen los personajes que surgen de sus cuadros".

Esta relación con sus creaciones, las tensiones que nacen en él como consecuencia de sus diálogo con ellas, producen un cambio radical en su ser, y se hace sentir la influencia importante de la energética de Wilhelm Reich, autor del notable libro La Función del Orgasmo. La Psiquiatría, las llamadas Ciencias Ocultas, lo llaman. Pudiéramos decir que en este momento Batlle siente la intuición de la vastedad infinita del Inconsciente y advierte que, en definitiva, su búsqueda puede obtener igual respuesta en la pintura que en cualquier otra actividad humana. Y vuelve a pintar.

2) Otro aspecto fundamental de su obra es el de "Forma Estructurada": entiendo que es aquella que resulta arquitectónicamente compuesta por volúmenes manifiestos o latentes, con encuentros de planos con aristas más o menos acusadas. En Batlle Planas, ese tipo de formas obedece a dos vertientes: a la obra de Cézanne, quien tuvo la genial intuición de componer los cuerpos y los paisajes como planos de color y de luz; y al primer cubismo de Picasso, que realizó la síntesis tal vez más fértil de la historia de la pintura al sintetizar la experiencia cezaniana con la escultura del África Negra. 
3) El Modernismo catalán, con Gaudí a la cabeza. Batlle se hubiera reconocido sin dudar un segundo en la libertad formal -sin embargo estructurada también- de las casas Milá, Batlló, o de ciertos portones del Parque Güell. Este modernismo, por cierto, venía a su vez del eco del Barroco sumado con el Romanticismo.

4) El clima de dulce melancolía de algunas calles de Buenos Aires, mezcla de Tango y arquitectura Colonial, como son por ejemplo Piedras, Salta, Independencia o Santiago del Estero (donde Batlle tenía su taller), tan indescriptibles como querer definir un sabor.

5) El pensamiento de los surrealistas, en cuanto se deriva del Psicoanálisis freudiano, y su uso de la asociación libre (que llamamos automatismo) como metodología de trabajo.

Por cierto que además de Batlle Planas hubo y hay en Argentina otros artistas que comprendieron en mayor o menor grado la auténtica fuerza de las dinámicas automáticas. Toda enumeración es incompleta y desagradable de hacer, y corre el riesgo de provocar resentimientos entre los no nombrados, pero debo correr el riesgo. Para un análisis más completo de este tema, me remito al artículo Ecos del Surrealismo en la Argentina, de Guillermo Whitelow, publicado en el catálogo de la exposición El caso Roberto Aizenberg, obras 1950,1994 realizada en el Centro Cultural Recoleta de Buenos Aires durante 2001.

Quiero rendir homenaje a un pintor de obra escasa, que de ninguna manera podemos considerar primitivo ni naïve, que ejerció siempre su oficio: el zapatero Casimiro Domingo, que dejó pinturas al pastel originalísimas, de estructura en espiral. Es una obra notablemente surrealista y marginal.

Entre los artistas de la misma generación de Batlle, debo destacar el esfuerzo sincero y comprometido de José Moraña; la última parte de la obra de Raquel Forner, y además el sostenido interés de la obra del yugoslavo naturalizado argentino Ducmelic. Otros, también de la misma generación, quisieron acercarse al Surrealismo creando obras de imaginación o metafísicas, sin tener que ver con el automatismo; me refiero entre otros a Antonio Berni, con una exposición "surrealista" en 1932, con influencia de De Chirico, y a algunos integrantes del Grupo Orión, formado por Ideal Sánchez, Vicente Forte, Luis Barragán, Orlando Pierri, Altalef, Miceli, Venier, Fuentes y Presas. Xul Solar, artista de primera importancia, fue un mago que utilizó la pintura, a veces automática, siempre fascinante, como medio para sus investigaciones esotéricas. También Vicente Caride es una figura principal dentro de este horizonte.

Entre los de Segunda Generación en el automatismo en Argentina, hay quienes trabajaron junto a Batlle. Efectivamente, tuvo cantidad de discípulos, que en mayor o menor medida continuamos la tarea por él emprendida, o por lo menos reconocemos su influencia en parte de nuestra obra. Fue uno de los pocos artistas argentinos que hicieron escuela: Juan Andralis, Roberto Aizenberg, Julio Silva, escultor y pintor que vive en París, yo mismo, Josefina Quesada, Inés Blumencweig, Dorita Nemirovsky, Roberto Mackintosh, Mario Gurfein, también en París, entre muchos otros.

Entre quienes no trabajaron con Batlle, pero que han hecho o están haciendo una obra total o parcialmente automática, están: Víctor Chab, Juana Butler, Noé Nojechowiz, Eduardo Bendersky, Emilio Renart, Olga Billoir, Campodónico, Artemio Alisio, Ana Tarsia, Mario Borio, Osvaldo Borda, Eduardo Markarian, Jorge Tapia, Carlos Agüero, Lilian Sussmann, Judith Blais- 
tein, Rebeca Guitelson, Josefina Auslender que reside en U.S.A., Gabriela Aberastury, Hugo Drucaroff, Martha Zuik, Carlos Tesarolo, etc.

Entre los de Tercera Generación, se destacan Catalina Chervin, Marcelo Bordese, Alejandro Puga y Adrián Burman, entre otros.

Entre los escultores, antes que a nadie debo mencionar al genio de Sesostris Vitullo como un notable antecedente; a Líbero Badii, escultor y pintor, figura poderosa, de la mayor importancia, nacido en Italia, pero con toda la obra hecha en Argentina, y al talentoso Aldo Paparella. Líbero Badii, con quien tuve el honor de compartir la sala de la Galería Ruth Benzacar en 1984, fue un gran compañero de ruta de Batlle, tenían muchos puntos de contacto en el uso de la energía creadora. Aunque con conceptualizaciones algo diferentes, practicó el automatismo con pasión juvenil. Otros escultores del mayor interés para el automatismo son Alberto Heredia, Carlos de la Mota, Hernán Dompé, Norberto Gómez, la escultora Tesso, Emilio Renart, parte de la obra de Leo Tavella, entre otros.

\section{Notas}

1. La traducción es del autor.

2. Ver Mercado de esclavos con el busto invisible de Voltaire, óleo de S. Dalí, 1940, en el Museo Salvador Dalí de St. Petersburg, Florida, U.S.A.

3. Texto publicado en Salvador Dalí, Retrospectiva 1920/80 Catálogo de la exposición realizada en el Centro Pompidou entre el 18/12/79 y el 21/4/80. Paris: Edic. Draeger. La traducción es del autor.

4. "bajo la roca" es la traducción textual que equivale en español a decir "bajo cuerda" o "bajo capa".

5. Para ampliar esta idea ver La Estructura Psicosocial del Arte. (Lorenzano, 1982:133 y sig.)

6. Los Cantos de Maldoror, Canto VI del Conde de Lautréamont.

7. Breton, A. L’ Amour Fou. Citado en: Nadeau, M. (1948:309).

\section{Referencias Bibliográficas}

A. A.V. V. (1981) Revista Cultural Correspondence No 12-14. Providence, USA.

A. A.V.V. (1991). Revista International Surrealist Bulletin No 1. Estocolmo.

A. A.V. V. (1970). Revista Opus Internacional No 19-20. París.

A. A.V.V. (1987/95). Revista Salamandra No 1, 2 , 3, 4, 5, 6 y 7. Madrid: Publicación del Grupo Surrealista.

A.A.V.V. (1991). Zullo. Granada: Revista Internacional por una Revolución en el Arte.

Aberastury, F. (1991). Escritos. Buenos Aires: Catálogos.

Alexandrian, S. (1985). Surrealist Art. New York: Thames and Hudson.

Arnheim, R. (1983). Arte y Percepción Visual. Madrid: Alianza Editorial.

Artaud, A. (1948). Lettres de Rodez. París: GLM.

Asociación Arabie-Sur.Seine. (1985). Revista Homnesies No 3. París: Asociación Arabie-Sur.Seine. CentrodeArteReinaSofía.(1991).AndréBretonyelsurrealismo.Madrid:CentrodeArteReinaSofía. Barthes, R. (1953). Le Degré Zéro de l'Écriture. París : Seuil 
Bataille, G. (1976). Oeuvres Complètes VIII. Le Surréalisme au Jour le Jour. París: Gallimard.

(1970). $3^{\circ}$ Convoi. En Le Groupe, la Rupture. París: Change, Seuil. Citado en el catálogo de la exposición El Surrealismo en España. Galería Multitud.

(1969). El Lenguaje de las Flores. En revista Documentos Caracas: Monte Ávila.

(1969). El Juego Lúgubre. En revista Documentos Caracas: Monte Ávila.

(1969). El Arte Primitivo. En revista Documentos Caracas: Monte Ávila.

Bauleo, A. (1997). Psicoanálisis y Grupalidad. Buenos Aires: Paidós.

Black Swan Press. (1973/1976/?). Revista Arsenal" No 2, 3, 4. Chicago: Black Swan Press. Publicación del Grupo Surrealista.

Black Swan Press. (1976). World Surrealist exhibition. Chicago: Black Swan Press.

Breton, A. (1985). Manifiestos del Surrealismo. Buenos Aires: Guadarrama.

(1985). Primer Manifiesto del Surrealismo. En Manifiestos del Surrealismo. Buenos Aires: Labor/Punto Omega.

(1975). Magia Cotidiana. Madrid: Espiral/Ensayo.

(1973). Génesis y perspectivas artísticas del surrealismo. En Antología (1913-1966). México: Siglo XXI Editores.

(1972). El Surrealismo, puntos de vista y manifestaciones. Barcelona: Barral.

(1945). Nadja. París: Gallimard.

(1937). L'amour fou. París: NRF.

Croce, B. (1992). Breviario de Estética. Barcelona: Planeta Agostini.

Cabie, R. y otros. (1984). Lecturas de Lacan - 1 - Escritos. Buenos Aires: Lugar.

Da Vinci, L. (1980). El Tratado de la Pintura. Murcia: Edic. Colegio de Aparejadores y Arquitec tos Técnicos de Murcia.

Dalí, S. (1935). Por la Paranoia Crítica. En La conquête de l'irrationnel. Paris: Édit. Surrealistes.

D’Angelo. R. y otros. (1984). Una introducción a Lacan. Buenos Aires: Lugar.

Ediciones del Grupo surrealista. (1996). Revista S.U.R.R. No1" París: Ediciones del Grupo surrealista.

Ferrua, P. (1982). Surréalisme et Anarchisme. París: Le monde libertaire.

Francone, G. y otros. (2006). Batlle Planas, una imagen persistente. Buenos Aires: Fundación Allón. Freud, S. (1979). Lo Siniestro. Junto a Hoffmann, E.T.A. El Hombre de la Arena. Barcelona: Pequeña Biblioteca Calamus Scriptorius.

(1948). Obras completas. Volumen I y II. Madrid: Editorial Biblioteca Nueva.

(1948). Obras Completas. Volumen I y II. Madrid: Biblioteca Nueva.

Fulcanelli. (1994). El misterio de las catedrales. Madrid: América Ibérica.

Galería Guillermo de Osma. Xul Solar. Madrid: Galería Guillermo de Osma.

Gérard, M. (1985). Dalí...Dalí...Dalí... Barcelona: Atlantis.

Gesell, A. y Amatruda, C. (1972). Embriología de la Conducta. Buenos Aires: Paidós.

Grupo Surrealista. (1982). Revista Signo Ascendente No 2-3. Buenos Aires: Grupo Surrealista.

(1980). Revista Signo Ascendente No 1". Buenos Aires: Grupo Surrealista.

Heidegger, M. (1980). El ser y el tiempo. Buenos Aires: Fondo de Cultura Económica.

Jakobson, R. (1985). Ensayos de Lingüística General. Barcelona: Planeta Agostini.

Joyce, J. (1995). Retrato del Artista Adolescente. Barcelona: RBA, Colección Narrativa Actual.

Klein, M. (1974). Obras Completas I. Buenos Aires: Paidós.

Klein, M. y Riviere, J. (1960). Las emociones básicas del hombre. Buenos Aires: Nova. 
Lacan, J. (1984) La instancia de la letra en el inconsciente o la razón desde Freud. En Escritos I. México: Siglo XXI.

(1984). El estadio del espejo. En Escritos I. México: Siglo XXI.

(1984). Subversión del sujeto y dialéctica del deseo. En Escritos II. México: Siglo XXI.

(1983). Lacan Oral. Buenos Aires: Xavier Bóveda.

(1981). Redondeles de Cuerda. En el Seminario 20 Aún. Barcelona - Buenos Aires: Paidós.

(1977) Los cuatro principios fundamentales del psicoanálisis. Seminario XI, Madrid: Barral.

(1975). El Seminario 1, 2, 3, 11, 20.Barcelona: Paidós.

(1974-1975). El Seminario R.S.I. En Ornicar Revista del Campo Freudiano de París.

Lautrémont, Conde de. (1964). Obras Completa. Buenos Aires: Edic. BOA.

(1949) Oeuvres Complètes. Paris: Club Français du livre.

Lévi-Strauss, C. (1994). Tristes Trópicos. Barcelona: Círculo de lectores. Lorenzano, César.

(1982). La Estructura Psicosocial del Arte. México: Siglo XXI.

Lyotard, J. F. (1979). Discurso, Figura. Barcelona: Gustavo Gigli.

Mead, G. (1978). The Surrealist Image: a Stylistic Study Berna: Lang.

Monod, J. (1970). El azar y la necesidad. Barcelona: Barral Editores.

Nadeau, M. (1948). Historia del Surrealismo. Buenos Aires: Santiago Rueda.

(1948). Documentos Surrealistas. París: Du Seuil.

Payró, J. E. (1949). Juan Batlle Planas. Buenos Aires: Instituto del Arte Moderno.

Paz, J. C. (1972). Memorias I. Buenos Aires: Ed. La Flor.

Picasso, P. (1980). A Retrospective, New York: Museo de Arte Moderno.

Pichon Riviére, E. (1947). Lo siniestro en la vida y en la obra del Conde de Lautréamont. Revista de psicoanálisis Año IV, No 4. Buenos Aires.

Recalcati, M. (2006). La sublimación artística y la Cosa. En: Las Tres Estéticas de Lacan. Buenos Aires: Editorial del Cifrado.

Reich, W. (1987). La función del orgasmo. Barcelona: Paidós.

Rimbaud, A. (1970). Una temporada en el Infierno. Buenos Aires: Edicom S.A. General Fabril Editora.

(1949). Oevres de Arthur Rimbaud. París: Mercure de France.

Sulic, S. (1980). Batlle Planas. Buenos Aires: Centro Editor de América Latina.

Schmitt, P. (1979). Salvador Dalí, Retrospectiva 1920/80. Paris: Draeger. Catálogo de la exposición realizada en el Centro Pompidou entre el 18/12/79 y el 21/4/80.

Van der Elst. (1947). El Ultimo Florecimiento de la Edad Media. Buenos Aires: Peuser.

Varela, L. (1971). Dalí. Buenos Aires:Centro Editor de América Latina.

Wertheimer, M. (1938). Laws of Organization in Perceptual Forms. En Ellis, W. (1938). A source book of Gestalt psychology. London: Routledge \& Kegan Paul.

Whitelow, G. (1981). Obras de Juan Batlle Planas. Buenos Aires: Museo Nacional de Bellas Artes, Ruth Benzacar y Banco Mercantil Argentino.

Worringer, W. (1942). La Esencia del Estilo Gótico. Biblioteca UPV, Revista de Occidente.

Yeats, W.B. (1991). Antología Poética. Madrid: Siruela. 
Summary: This essay will talk about the creative process in the visual arts. From psychic automatism as a precedure and artistic manner influenced by surrealism, it's study goes forward as a complex process that merges the intelectual, the sensible and the unqualifiable. It's fundation has it's roots in psychoanalysis, semiotics and historical creative practices. From the artistic experience of the author, different methods are put in discussion, methods that can be considered as a systematization for inspiration. To conclude, the text brings a remark of the surrealist movement, specially in Argentina from the formative legacy of Battle Planas.

Key words: Art - creativity - image - Painting - psychic automatism - Psychoanalysis - Surrealism.

Resumo: $\mathrm{O}$ ensaio aborda a questão do processo creativo nas artes visuais. A partir do automatismo psíquico como procedimento e discursividade artística impressa pelo surrealismo, estudia-se como processo complexo que concentra o intelectivo, o sensível e o incosificável. Seus fundamentos estão no Psicoanálise, a Semiótica e os rastros históricos das práticas criadoras. A partir da propria experiência artística do autor, se discutem aspectos metodológicos que podem ser considerados como uma sistematização da inspiração. O texto também inclui uma resenha do movimento surrealista em Argentina a partir do legado formativo de Batle Planas.

Palavras chave: Arte - automatismo psíquico - creatividade - imagem - Pintura - Psicoanálise - Surrealismo. 